\title{
Effect of chelating agent edta (ethylene diamine tetra acetic acid, disodium salt) as feed additive on controlling heavy metals residues in Sarotherodon galilaeus fish
}

\author{
Hayam D.Tonsy $^{1}$ and Abeer S. Abdel-Rahman ${ }^{2}$ \\ 1-Animal Production Research Institute, By-product utilization Dept., ARC, Dokki, Giza, \\ Egypt. \\ 2- Animal Health Research Institute, Biochemistry Dept., ARC, Dokki, Giza, Egypt. \\ e.mail:drabeersaid@gmail.com
}

\section{ABSTRACT}

The study was undertaken in order to determine the effect of chelating agent EDTA as feed additive on controlling heavy metals (Pb\&Cd) which cause some dangerous diseases and its impact on growth performance, feed and protein utilization, carcass composition and biochemical parameters in mono sex Galilee Tilapia fingerlings were studied.

Galilee tilapia fingerlings were collected from El-Zaheria village, Abo- Hamad, Sharkia (recorded as polluted area) and analyzed for lead, cadmium and zinc contamination at the start of experiment. The fish were divided into 5 treatments EDTA (ethylene diamine tetra acetic acid, disodium salt) were included in the diets at a rate of $0.0,0.5,1.0,1.5$ and $2.0 \%$. The diets were formulated to be iso-nitrogenous $(30.19 \% \pm 0.15$ crude protein) and iso-caloric (4459.49 $\pm 85 \mathrm{kcal}$ gross energy $/ \mathrm{kg}$ diet). After that, the fish were randomly distributed into 15 aquarium (5 fish/aquaria) of Galilee Tilapia fingerlings, Each diet treatment was applied to triplicate groups $(54.2 \pm 0.99 \mathrm{~g} /$ fish $)$ at rate six days of the week and the experiment extended for 49 days.

The obtained results showed that, lead $(\mathrm{Pb})$ and cadmium $(\mathrm{Cd})$ concentrations were significantly decreased in all EDTA treatments in the whole body and fish flesh of Galilee Tilapia fingerlings compared with those at the start of the experiment and control group (E1, 0.0\% EDTA) .

The biochemical parameters were significantly improved at $(\mathrm{P} \leq 0.05)$. The uric acid and cholesterol levels were significantly decreased. The highest weight gain (WG), average daily gain (ADG), and specific growth weight (SGR) and protein and nutrient utilization at $(\mathrm{P} \leq 0.05)$ were recorded by E4 (1.5\% EDTA) followed by E3 (1.0\% EDTA), respectively.

In conclusion the addition of EDTA to contaminated fish with heavy metals, reduced significantly $\mathrm{Pb}$ and $\mathrm{Cd}$ levels. The obtained results showed that all the tested biochemical parameters and growth performance, protein, nutrient utilization body carcass were improved due to EDTA application and the effects were more pronounced at $1.5 \%$ EDTA/ $\mathrm{kg}$ diet, which are considered as the optimum dose that improve the healthy status and growth parameters of fish in this experiment.

Keywords: EDTA, heavy metals Galilee Tilapia fingerlings, growth performance, feed utilization, biochemical parameters.

\section{INTRODUCTION}

Heavy metals discharged to the aquatic environment are of great concern, it has been amply demonstrated that large concentrations of heavy metals in food will 
cause severe and dangerous health problems. Heavy metals ions accumulate in all tissue of aquatic organisms either directly from surrounding water or indirectly through sediments whether or not they are essential to metabolism (Rainbow, 2007).

Among the most important heavy metals that pollute the water and then concentrated in fish are cadmium and lead, which cause some dangerous diseases, as Neurosis, loss of memory, disorder of kidney function, and may lead to kidney failure in advanced cases. Therefore continuous trials to clear fish from these heavy metals are one of the main objectives to obtain safe food source for animals and human.

Various agents [ethylene diamine tetra acetic acid, (EDTA), Nitrilotri acetic acid (NTA), and diethylene triamine penta acetic acid, (DTPA)], are known to reduce metal accumulation in tissues of aquatic animals. Kargin, (1996) showed that EDTA and NTA had reduced cadmium toxicity in aquatic organisms.

EDTA is a common sequestrant and antioxidant added to foods, body care, and household products. Binds trace minerals such as lead, copper, iron, cadmium and nickel that may be present in the product. When it is added as an antioxidant, EDTA prevents oxygen from causing color changes and rancidity. (Ben Best, 2009)

EDTA has two advantages with respect to other compounds-its relative low biodegradability in groundwater systems (Nowack, 1996) and its strong complexing capacity with heavy metals (Kedziorek and Bourg, 2000).

There are several literature reviews available on EDTA as strong chelating agent that has different binding properties affecting the release and mobilization of the heavy metals. EDTA can be applied in aquatic environment as a measure to protect aquatic organisms from heavy metal poisoning and or remove the accumulated levels from tissue due to comparable complex formation stability criteria. Abd-El Rahman et al. (2009) reported that the highest removal recoveries from muscles were obtained upon immersing crayfish in aquaria treated with EDTA.

Rengswamy Gopal et al. (2009) found that total protein contents decreased due to nickel chloride toxicity had been returned nearly to normal levels by using $\mathrm{Ca} \mathrm{Na2}$ EDTA. Kargin (1996) reported that the use of EDTA significantly reduced cadmium accumulation in $\mathrm{T}$. zilli tissues and that the highest reduction in accumulated $\mathrm{Cd}$ due to the use of EDTA occurred in gills followed by liver and muscles.

FDA (1950) has approved EDTA (synthetic amino acid) as a food additive that is generally recognized as safe (See the US Code of Federal Regulations-21 CFR 172.135 and 21 CFR 173.315). The World Health Organization (WHO, 1992) recommend that EDTA can be added to the diet of children in poor countries to enhance mineral absorption, particularly of iron and zinc. Fidler et al. (2003) reported that in Asia. NaFeEDTA is a potentially useful fortificant because it can be added to Fish and soy sauce which have been suggested as food vehicles for iron fortification without causing precipitation during storage. Also Morel et al. (1987) reported that EDTA can greatly reduce the production of free radical. It is not possible for free radical reactions to be catalyzed by metallic ions in the presence of EDTA.

Chelation is a capture of positively-charged metal ions by a large molecule. The most widely used chelating molecule is EDTA, which has the capacity to chelate almost every positive ion in the periodic table. It has a very strong list of preferences, which are called stability constants (formation constant).

Mode of action of EDTA: When a molecule of EDTA gets near a toxic mineral, such as lead or mercury, it grasps the destructive particle and binds tightly with it, pulling it out of the membrane or body tissue, it was embedded in. Since EDTA is an artificial amino acid, and since the body regards it as a foreign substance, the body 
eliminates the entire particle (the heavy particle coated with EDTA). Both the EDTA and the toxic substance are excreted by the kidneys Gordon, Gary (1997).

The present study was carried out to investigate the eliminating effect of EDTA on some heavy metals abundance in Galilee Tilapia fingerlings together with the effect of EDTA on the biochemical profile, growth performance, feed utilization and proximate analysis of Galilee Tilapia fingerlings.

\section{MATERIALS AND METHODS}

Mono sex Gallily Tilapia fingerlings from El -Zaheria village, Abo- Hamad, Sharkia, were collected and analyzed for lead, cadmium and Zinc contamination at the start of the experiment. This site were selected as a polluted area (agricultural drainage area) as recorded by Khater, (2011).

Seventy-five mono-sex Galilee Tilapia fingerlings of $(54.2 \pm 0.99 \mathrm{~g})$ were allotted into 5 treatments. Diets were formulated by mixing the dry ingredient thoroughly. All diets were pressed thorough meat mincer $(0.5 \mathrm{~mm}$ diameter $)$ and sun dried for 3 days. Representative samples of fish whole body and fish flesh were taken at the start and at the end of the study and frozen at $-18^{\circ} \mathrm{C}$ to be used for chemical analysis. The diets were formulated to be iso-nitrogenous $(30.19 \% \pm 0.15$ crude protein) and iso-caloric $(4459.49 \pm 85.59 \mathrm{kcal}$ gross energy/ $\mathrm{kg}$ diet$)$ and contained $0,0.5,1,1.5 \& 2 \%$ of EDTA (Table 1). The fish were adapted the laboratory conditions for 5 days. After that fish were randomly distributed into $1570-\mathrm{L}$ aquaria $(60 \mathrm{X} 40 \mathrm{X} 30 \mathrm{~cm})$ at a rate of 5 fish/aquarium. Each treatment was represented by three replicates. Fish were fed the tested diets at a rate of $3 \%$ of their wet body weight per day, in two equal portions, at 9.00 and 14.00 h, 6 days a week for 49 days. Every week, fish were collected, counted, and group-weighed and water changed by third every three days by siphon. The amount of feed was readjusted bi-weekly according to the change in body weight.

Table 1: Composition and proximate analysis of the tested diets fed of Galilee Tilapia fingerlings

\begin{tabular}{|l|l|l|l|l|l|}
\hline Ingredients (\%) & \multicolumn{5}{|l|}{ Treatments } \\
\hline & E1 & E2 & E3 & E4 & E5 \\
\hline Fish meal (65\% CP) & 15 & 15 & 15 & 15 & 15 \\
\hline Soybean meal (44\% CP) & 32 & 32 & 32 & 32 & 32 \\
\hline Wheat bran & 6 & 6 & 6 & 6 & 6 \\
\hline Yellow corn & 36 & 35.5 & 35 & 34.5 & 34 \\
\hline Corn gluten & 5 & 5 & 5 & 5 & 5 \\
\hline Corn oil & 4 & 4 & 4 & 4 & 4 \\
\hline Vit. \& Min. premix * & 1 & 1 & 1 & 1 & 1 \\
\hline Di Ca phosphate & 0.50 & 0.50 & 0.50 & 0.50 & 0.50 \\
\hline Calcium carbonate & 0.50 & 0.50 & 0.50 & 0.50 & 0.50 \\
\hline EDTA & 0.0 & 0.5 & 1.0 & 1.5 & 2.0 \\
\hline Total & 100 & 100 & 100 & 100 & 100 \\
\hline Proximate analysis (\%) & \multicolumn{5}{|l|}{} \\
\hline Moisture (\%) & 5.94 & 6.22 & 6.12 & 6.15 & 6.23 \\
\hline Crude protein (\%) (CP) & 30.26 & 30.22 & 30.19 & 30.15 & 30.11 \\
\hline Ether extract (\%) (EE) & 5.78 & 5.62 & 5.73 & 4.56 & 4.90 \\
\hline Crude fiber (\%) (CF) & 4.61 & 5.21 & 5.07 & 5.02 & 4.97 \\
\hline Ash (\%) & 7.76 & 7.24 & 7.94 & 8.06 & 8.80 \\
\hline NFE (\%) & 51.59 & 51.71 & 51.07 & 52.21 & 51.22 \\
\hline GE (Kcal/Kg)** & 4502.28 & 4480.88 & 4459.49 & 4438.09 & 4416.69 \\
\hline
\end{tabular}

*Contains per kg: vitamin A, 4.8 m. I.U; vit D3, 0.8 m.I.U; vit E, 4.0 g; vit. K, 0.8 g; vit B1, 0.49, vit. B2, 1.6 g; vit. B6, 0.6 g; vit. B12, 4 mg; Pantothenic acid 4 g; Nicotinc acid 8 g; Folic acid, 400 mg; Biotin, 20 mg; Choline chloride, $200 \mathrm{mg}$; Copper, $4.0 \mathrm{~g}$; Iodine, 0.4g; Iron, $12 \mathrm{mg}$; Manganese, $22 \mathrm{~g}$; Zinc $22 \mathrm{~g}$ and Selenium $0.04 \mathrm{~g}$. **after Gobling (1983). 


\section{Water quality.}

Water temperature was $25 \pm 2^{\circ} \mathrm{C}$. Rate of water flow was adjusted to maintain oxygen saturation above $70 \%$. The water quality parameters in the system were monitored every other day according to (APHA, 1992). The ranges were: dissolved oxygen 6-7.5 mg/l, total ammonia $0.1-0.3 \mathrm{mg} / 1$ and $\mathrm{pH} 7-8$. No critical values were detected for nitrite (NO2) and nitrate (NO3) radicals. The $\mathrm{pH}$ and water temperature values were determined by $\mathrm{pH}$ meter and digital thermometer. Dissolved oxygen was monitored by using oxygen meter, Jan way model 9071.

\section{Estimation of heavy metals:}

At the start of the experiment and at the end of the experimental period Fish whole body and flesh were prepared and digested according to the technique recommended by Khan et al. (1995). Where one gram of each sample was macerated and put in $100 \mathrm{ml}$ flask, ten $\mathrm{ml}$ of 7:3 mixture of ultra pure concentrated nitric acid (HNO3: HClO4) were added to the tissue samples. The flask was tightly closed. The content was gently shaken and allowed to stand overnight at room temperature for complete digestion. The flask was warmed at $95^{\circ} \mathrm{C}$ until completely evaporated, and then allowed to cool. The residues were redissolved into $10 \mathrm{ml} \mathrm{N}$ nitric acid. The resulting solution was filtrated through Whatman paper No. 1. The filtrate was collected in tubes and kept at room temperature until analyzed by using atomic absorption spectrophotomete. Lead, Cadmium, Zinc Calcium, Phosphorus, Sodium and Potassium, were measured by using Air/Acetylene flame Atomic Absorption spectrophotometer (UNICAM 969 AA spectrometer) and residue levels are expressed as ppm.

\section{Blood samples:}

Blood samples were collected at the start of the experiment and at the end of the experimental period from caudal vein in dry sterilized centrifuge, and allowed to clot at room temperature. Samples were then centrifuged to separate sera, which were kept at $-20^{\circ} \mathrm{C}$ till used. Aspartate aminotransferas (AST) and alanine aminotransferas (ALT) activities were determined according to Reitman and Frankel (1957). Alkaline phosphates, uric acid and creatinine were determined according to Kilichling \& Freiburg, (1951), Schultz (1984) and Husdan \& Repoport (1968). Total protein (TP) and albumin were determined according to Henry (1964) and Drupt (1974), respectively, Blood serum globulin and albumin globulin ratio calculated mathematically. Cholesterol were determined according to Richmound (1973)

\section{Chemical analysis:}

Chemical analysis of diets, fish whole body and fish flesh were made as described by AOAC (2000).

\section{Measurements of growth and feed utilization.}

Total weight gain, average daily gain, specific growth rate, feed conversion ratio, protein and energy utilization were determined according to Recker, (1975) and Castell and Tiewers, (1980).

- Average Weight gain, AWG $(\mathrm{g} /$ fish $)=[$ Average final weight $(\mathrm{g})$ - Average initial weight $(\mathrm{g})$.

- Average daily gain, ADG (G/fish/day) $=[\mathrm{AWG}(\mathrm{g}) /$ experimental period (d)].

- Specific growth rate, SGR (\%day) $=100(\ln$ final weight $(\mathrm{g})-\ln$ initial weight $)$ (g) / experimental period (d)].

- Feed conversion ratio $(\mathrm{FCR})=$ dry matter intake $(\mathrm{g}) /$ total gain $(\mathrm{g})$.

- Protein efficiency ratio $(\mathrm{PER})=$ total gain $(\mathrm{g}) /$ protein intake $(\mathrm{g})$.

- Protein productive value $(\mathrm{PPV} \%)=(\mathrm{PT}-\mathrm{PI}) \times 100 /$ protein intake $(\mathrm{g})$. 
Where: PT: Protein content in fish carcass at the end and PI: Protein content at the start.

- Energy utilization $($ EU \%) $=($ ET-EI $) \times 100 /$ Energy intake $(k c a l)$.

Where: ET: Energy in fish carcass (kcal) at the end and EI: Energy in fish carcass at the start.*whole body, **for fish flesh.

Statistical analysis:

The obtained data were subjected to statistical evaluation using one way analysis of variance (ANOVA) of the general linear model (GLM) using SAS (1993) statistics package. Duncan's multiple range test (Duncan, 1955) was used to test the significance of differences among means at $\mathrm{P} \leq 0.05$.

\section{RESULTS AND DISSCUSION}

\section{Heavy metals in whole body and fish flesh.}

At the start of the experiment $\mathrm{Pb}$ concentrations in whole body and fish flesh were (2.6 \pm 0.03 and $1.24 \pm 0.06)$ respectively (Table 2$)$. The $\mathrm{Cd}$ concentration were ranged between $(1.5 \pm 0.06$ and $0.22 \pm 0.01)$ in whole body and fish flesh respectively. $\mathrm{Zn}$ level was ranged between $(5.5 \pm 0.58$ and $1.35 \pm 0.02)$ in whole body and fish flesh at the start of the experiment. In this regard, Khater concentrations ranged between $(-3.871 \pm 0.793$ and $2.945 \pm 0.341)$ and $0.992 \pm 0.196$ and $\underline{0.610} \pm \underline{0.086}$ in muscle tissue of Nile tilapia, OrechromisOreochromis niloticus-, respectively.

Table 2: Heavy metals residues in whole body and fish flesh with different levels of EDTA at the end and the start of the experimental period (49 days).

\begin{tabular}{|l|l|l|l|l|l|l|}
\hline \multirow{2}{*}{ Item.(ppm) } & \multicolumn{2}{c|}{ Pb } & \multicolumn{2}{c|}{ Cd } & \multicolumn{2}{c|}{ Zn } \\
\cline { 2 - 7 } Treatment & Whole body & Fish flesh & Whole body & Fish flesh & Whole body & Fish flesh \\
\hline Start time & $2.6^{\mathrm{a}} \pm 0.03$ & $1.24^{\mathrm{a}} \pm 0.06$ & $1.5^{\mathrm{a}} \pm 0.06$ & $0.22^{\mathrm{a}} \pm 0.01$ & $5.5^{\mathrm{a}} \pm 0.58$ & $1.35^{\mathrm{a}} \pm 0.02$ \\
\hline E1 $(0.0 \%)$ & $2.55^{\mathrm{a}} \pm 0.29$ & $1.21^{\mathrm{a}} \pm 0.06$ & $1.40^{\mathrm{ab}} \pm 0.58$ & $0.21^{\mathrm{a}} \pm 0.01$ & $5.30^{\mathrm{a}} \pm 0.58$ & $1.33^{\mathrm{a}} \pm 0.02$ \\
\hline E2 $(0.5 \%)$ & $2.35^{\mathrm{b}} \pm 0.03$ & $0.92^{\mathrm{b}} \pm 0.06$ & $1.25^{\mathrm{bc}} \pm 0.03$ & $0.18^{\mathrm{b}} \pm 0.01$ & $5.30^{\mathrm{a}} \pm 0.06$ & $1.20^{\mathrm{ab}} \pm 0.06$ \\
\hline E3 (1.0\%) & $1.85^{\mathrm{c}} \pm 0.03$ & $0.64^{\mathrm{c}} \pm 0.06$ & $1.08^{\mathrm{c}} \pm 0.11$ & $0.16^{\mathrm{b}} \pm 0.01$ & $4.45^{\mathrm{a}} \pm 0.09$ & $1.13^{\mathrm{abc}} \pm 0.12$ \\
\hline E4 $(1.5 \%)$ & $1.45^{\mathrm{d}} \pm 0.09$ & $0.52^{\mathrm{c}} \pm 0.05$ & $1.05^{\mathrm{c}} \pm 0.03$ & $0.13^{\mathrm{c}} \pm 0.01$ & $5.55^{\mathrm{a}} \pm 0.38$ & $1.10^{\mathrm{bc}} \pm 0.06$ \\
\hline E5 (2.0\%) & $1.23^{\mathrm{e}} \pm 0.09$ & $0.33^{\mathrm{d}} \pm 0.02$ & $1.03^{\mathrm{c}} \pm 0.09$ & $0.11^{\mathrm{c}} \pm 0.01$ & $5.12^{\mathrm{a}} \pm 0.17$ & $0.96^{\mathrm{bc}} \pm 0.20$ \\
\hline
\end{tabular}

$\mathrm{a}, \mathrm{b}, \mathrm{c}$; means within the same row with different superscript are significantly $(\mathrm{P} \leq 0.05)$.

$\mathrm{Pb}=$ lead, $\mathrm{Cd}=$ cadmium And $\mathrm{Zn}=$ zinc

These concentrations which-were higher than the permissible limits $(0.5$ and $0.05 \mathrm{ppm}$ for $\mathrm{Pb}$ and $\mathrm{cd}$, respectively) -recommended by WHO (1992). On the other hand $_{2} \mathrm{Zn}$ concentrations in the present study are less than the limit (50 ppm) recommended by WHO (1992). Furthermore, the concentrations of -Pb and $\mathrm{Cd}$ in the whole-fish body and fish flesh were significantly decreased significantly in fish fedwith all EDTA-supplemented diets treatments in the whole body and fish flesh of T. gallilea fingerlingsas -compared to those at the start of the experiment and control group (E1, $0.0 \%$ EDTA). The significance degree of $\mathrm{Pb}$ and $\mathrm{Cd}$ elimination increased with increasing the EDTA percentage from $0.5,1.0,1.5$, to $2.0 \%$ in - $(\mathrm{E} 2, \mathrm{E} 3, \mathrm{E} 4$ and E5Table 2).

Zn level was ranged between $(5.5+0.58$ and $1.35+0.02)$ in whole body and fish flesh at the start of the experiment. Similar results were found by Khater, (2011) whe reported that $Z n$ levels lie within the safe limits $(50 \mathrm{ppm})$ recommended by $\mathbf{W H O}$, (1992) when worked on muscle tissue of Orechromis niloticus. While Zn concentration was did not affected at all in whole-fish body, body; meanwhile its level in fish flesh was significantly decreased significantly with E4 and E5 (at $1.5 \%$ and \& 
2.0\% EDTA) in fish flesh. Ben Best (2009) reported that, EDTA is a nonspecific chelator, and if there is not an ample supply of minerals with a higher stability constant, then EDTA could potentially remove essential minerals. It would ultimately depend on the amount of heavy metals in the system, the $\mathrm{pH}$ of the system, etc. If there is not much lead or mercury in the system for instance, then EDTA could remove zinc, which is rapidly excreted in the urine.

It is clear from data presented in table (2) that the trend of heavy metal clearing in the whole body is as the same as in fish flesh. The present results indicated that EDTA has an effective role in reducing $\mathrm{Pb}$ and $\mathrm{Cd}$ bioaccumulation in whole fish and in fish flesh. These results are in agreement with Shalaby (2003) on Nile tilapia (Oreochromius niloticus), Kargin (1996) on Tilapia zillii and Abd-El Rahman et al. (2009) on cray fish Procambarue clarkii (crustacean).

Micro elements in whole body and fish flesh.

Results shown in table (4) indicatedThere are no insignificantly difference in ealcium $(\mathrm{Ca}))_{2}$ sodium $(\mathrm{Na})_{2}$ and potassium $(\mathrm{K})$ concentrations -in the whole-fish body and fish flesh between the start of the experiment, E1, E2 and -E3 treatments (Table 3). Meanwhile E4 showed a significant was significantly decreased within $\mathrm{Ca}$ only ${ }_{2}$ while- E5 had a significante decreased inwith $\mathrm{Ca}, \mathrm{Na}$ and $\mathrm{K}$. On the other hand $\mathrm{P}_{2}$ in both of whole body and fish flesh, wasdid not be affected throughout the experimental period due to EDTA supplementation.

The formation constant (which reflect the binding force of EDTA with metal) for $\mathrm{Pb}$ and $\mathrm{Cd}$ are (18.04) and (-16.40), respectively, while they are $(-10.69),\left(1.66_{2}\right)$ and $(-0.8)$. for $\mathrm{Ca}, \mathrm{Na}$ and $\mathrm{K}_{2}$ which cleared the fact that the formation constants in general considered greater for toxic metals than for essential minerals. $\mathrm{So}_{2}$ the binding with the most toxic minerals will generally be stronger- (Ben Best, (-2009).

Table 3: Micro elements in whole body and fish flesh with different levels of EDTA at the end and the start of the experimental period (49 days).

\begin{tabular}{|c|c|c|c|c|c|c|c|c|}
\hline \multirow[t]{2}{*}{ Treatment } & \multicolumn{2}{|c|}{ Ca } & \multicolumn{2}{|c|}{$\mathrm{Na}$} & \multicolumn{2}{|c|}{$\mathbf{k}$} & \multicolumn{2}{|c|}{ p } \\
\hline & Whole body & Fish flesh & Whole body & Fish flesh & Whole body & Fish flesh & Whole body & Fish flesh \\
\hline Start time & $15.0^{\mathrm{a}} \pm 0.12$ & $13.80^{\mathrm{a}} \pm 1.31$ & $170.5^{\mathrm{ab}} \pm 2.89$ & $138.33^{\mathrm{a}} \pm 0.33$ & $5.5^{\mathrm{a}} \pm 0.12$ & $5.37^{\mathrm{a}} \pm 0.18$ & $5.17^{\mathrm{a}} \pm 0.22$ & $3.37^{\mathrm{a}} \pm 0.17$ \\
\hline E1 $(0.0 \%)$ & $15.05^{\mathrm{a}} \pm 0.26$ & $12.80^{\mathrm{b}} \pm 1.31$ & $175.5^{\mathrm{a}} \pm 0.33$ & $137.33^{\mathrm{ab}} \pm .33$ & $5.35^{\mathrm{ab}} \pm 0.26$ & $5.17^{\mathrm{ab}} \pm 0.18$ & $5.15^{\mathrm{a}} \pm 0.32$ & $3.57^{\mathrm{a}} \pm 0.18$ \\
\hline E2 $(0.5 \%)$ & $14.35^{\mathrm{a}} \pm 1.12$ & $12.6^{\mathrm{b}} \pm 1.55$ & $161.5^{\mathrm{ab}} \pm 0.91$ & $136.0^{\mathrm{ab}} \pm 0.0$ & $5.10^{\mathrm{bc}} \pm 0.0$ & $5.20^{\mathrm{ab}} \pm 0.06$ & $5.20^{\mathrm{a}} \pm 0.12$ & $3.57^{\mathrm{a}} \pm 0.03$ \\
\hline E3 $(1.0 \%)$ & $15.20^{\mathrm{a}} \pm 0.0$ & $12.90^{\mathrm{ab}} \pm 0.75$ & $162.5^{\mathrm{ab}} \pm 0.29$ & $133.0^{c} \pm 0.58$ & $5.0^{\mathrm{bc}} \pm 0.58$ & $5.05^{\mathrm{ab}} \pm 0.09$ & $5.10^{\mathrm{a}} \pm 0.12$ & $3.85^{\mathrm{a}} \pm 0.14$ \\
\hline $\mathrm{E} 4(1.5 \%)$ & $11.5^{b} \pm 0.0$ & $11.70^{\mathrm{b}} \pm 0.92$ & $163.0^{\mathrm{ab}} \pm 0.0$ & $137^{\mathrm{ab}} \pm 0.58$ & $5.15^{\mathrm{abc}} \pm 0.03$ & $5.15^{\mathrm{ab}} \pm 0.03$ & $5.4^{\mathrm{a}} \pm 0.52$ & $3.70^{\mathrm{a}} \pm 0.12$ \\
\hline E5 $(2.0 \%)$ & $10.87^{\mathrm{b}} \pm 0.28$ & $10.80^{\mathrm{c}} \pm 1.07$ & $158.67^{b} \pm 8.69$ & $135^{\mathrm{bc}} \pm 1.73$ & $4.90^{c} \pm 0.0$ & $4.90^{b} \pm 0.0$ & $4.73^{\mathrm{a}} \pm 0.33$ & $3.53^{\mathrm{a}} \pm 0.18$ \\
\hline
\end{tabular}

$\mathrm{a}, \mathrm{b}, \mathrm{c}$; means within the same row with different superscript are significantly $(\mathrm{P} \leq 0.05)$.

$\mathrm{Ca}=$ calcium, $\mathrm{Na}=$ sodium, $\mathrm{K}=$ potassium and $\mathrm{P}=$ phosphorus

\section{Biochemical parameters:}

As seen in Table (4) The serum ALT and AST activities increased significantly in fish at the start of the experiment and The addition of EDTA decreased ALT and AST activity to be near the control especially the groups exposed to $0.5,1.0$ \& $1.5 \%$ EDTA (E2, E3,\& E4). The AST activity in fish exposed to different EDTA percentage decreased gradually, while it increased at 2\% EDTA (E5).

Table 4: Serum analysis of Galilee Tilapia fingerlings with different levels of EDTA throughout the experimental period (49 days) and at the start of the experiment.

\begin{tabular}{|c|c|c|c|c|c|c|}
\hline \multirow{2}{*}{ Item } & \multicolumn{6}{|l|}{ Treatments } \\
\hline & E1 & E2 & E3 & E4 & E5 & Start time \\
\hline ALT ( Iu/L) & $24.33^{\mathrm{d}} \pm 0.6$ & $24.0^{\mathrm{d}} \pm 0.69$ & $25.0^{\mathrm{c}} \pm 1.1$ & $25.0^{\mathrm{c}} \pm 0.98$ & $27.0^{b} \pm 0.69$ & $39.0^{\mathrm{a}} \pm 1.24$ \\
\hline AST (Iu/L) & $19.5^{\mathrm{bc}} \pm 0.58$ & $19.0^{\mathrm{bc}} \pm 0.66$ & $18.0^{\mathrm{bc}} \pm 0.69$ & $17.0^{\mathrm{c}} \pm 0.66$ & $20.0^{b} \pm 0.75$ & $27.0^{\mathrm{a}} \pm 1.21$ \\
\hline Alk (Iu/L) & $140.5^{\mathrm{a}} \pm 0.76$ & $140.5^{\mathrm{a}} \pm 0.87$ & $135.0^{b} \pm 0.0$ & $139.0^{\mathrm{a}} \pm 0.58$ & $139.0^{\mathrm{a}} \pm 0.58$ & $139.33^{\mathrm{a}} \pm 0.33$ \\
\hline UA (mg/dl) & $10.4^{a}+0.06$ & $9.3^{\mathrm{a}} \pm 0.06$ & $7.65^{b} \pm 0.02$ & $7.3^{b} \pm 0.03$ & $6.4^{\mathrm{c}} \pm 0.58$ & $10.5^{\mathrm{a}} \pm 0.79$ \\
\hline Creat. (mg/dl) & $0.24^{\mathrm{a}} \pm 0.01$ & $0.23^{\mathrm{a}} \pm 0.02$ & $0.24^{\mathrm{a}} \pm 0.03$ & $0.23^{\mathrm{a}} \pm 0.02$ & $0.22^{\mathrm{a}} \pm 0.01$ & $0.24^{\mathrm{a}} \pm 0.01$ \\
\hline TP. (g/dl) & $3.53^{\mathrm{a}} \pm 0.3$ & $3.55^{\mathrm{a}} \pm 0.26$ & $3.75^{\mathrm{a}} \pm 0.26$ & $3.75^{\mathrm{a}} \pm 0.03$ & $3.63^{\mathrm{a}} \pm 0.18$ & $3.77^{\mathrm{a}} \pm 0.24$ \\
\hline
\end{tabular}




\begin{tabular}{|l|c|c|c|c|c|c|}
\hline Alb. $(\mathrm{g} / \mathrm{dl})$ & $1.54^{\mathrm{a}} \pm 0.05$ & $1.55^{\mathrm{a}} \pm 0.04$ & $1.46^{\mathrm{a}} \pm 0.03$ & $1.60^{\mathrm{a}} \pm 0.0$ & $1.47^{\mathrm{a}} \pm 0.06$ & $1.49^{\mathrm{a}} \pm 0.11$ \\
\hline Glob. $(\mathrm{g} / \mathrm{dl})$ & $1.99^{\mathrm{ab}} \pm 0.24$ & $2.21^{\mathrm{a}} \pm 0.11$ & $2.29^{\mathrm{a}} \pm 0.23$ & $2.15^{\mathrm{a}} \pm 0.03$ & $2.16^{\mathrm{a}} \pm 0.23$ & $2.28^{\mathrm{a}} \pm 0.17$ \\
\hline A /G & $0.70^{\mathrm{ab}} \pm 0.13$ & $0.65^{\mathrm{b}} \pm 0.07$ & $0.74^{\mathrm{a}} \pm 0.01$ & $0.70^{\mathrm{ab}} \pm 0.03$ & $0.66^{\mathrm{b}} \pm 0.10$ & $0.79^{\mathrm{a}} \pm 0.04$ \\
\hline Chol. $(\mathrm{mg} / \mathrm{l})$ & $125.37^{\mathrm{b}} \pm 1.31$ & $98.0^{\mathrm{c}} \pm 0.75$ & $75.0^{\mathrm{d}} \pm 0.92$ & $100.0^{\mathrm{c}} \pm 1.07$ & $130.0^{\mathrm{a}} \pm 1.31$ & $135.0^{\mathrm{a}} \pm 1.35$ \\
\hline
\end{tabular}

$\mathrm{a}, \mathrm{b}, \mathrm{c}$; means within the same row with different superscript are significantly $(\mathrm{P} \leq 0.05)$. Alanine aminotransferase (ALT), Aspartate aminotransferase y (AST)_Alkaline phosphatase (ALk), Uric acid (UA), Creatinine (Creat), Total protein (TP), Albumin (Alb), globulin(Glob), Albumin/Globulin ratio (A/G) and Cholesterol (Chol).

The activity of AST and ALT enzymes in blood may also be used as a stress indicator. The significant changes in activities of these enzymes in blood serum indicates tissue impairment caused by stress; (James et al. (1991; and Svoboda (2001). In the present study, there were are significant changes in AST and ALT activities in serum of the start of the experiment fish (exposed to pollution) compared to that of -control group. The increase of serum AST and ALT may be attributed to the hepatocellular damage or cellular degradation by these heavy metals, perhaps in liver, heart or muscle ${ }_{\overline{5}}$ (Yamawaki et al. (1986). These results are in agreement with those of Shalaby (1997) who found that sublethal concentration of Cd had caused significant increases in activities of serum AST and ALT of common carp after 7 and 15 days, and on Tilapia zillii -, (Shalaby (-2003)-.

The alkaline phosphatase (ALPH.Ph.) activity showed nonun-significant variation with the use of EDTA except with E3_(1.0\% EDTA) where it induced significant decrease in ALPk. Ph. activity compared to all other treatments._Similar results were obtained by Shalaby (2003) after 45 days of treatments with EDTA in $T$. zillii-.

Uric acid levels (UA) in all treatments decreased significantly compared with the start of the experiment and E1 (control), and was highly significant with E4 $(2.0 \%$ EDTA). Creatinine (Creat.) decreased insignificantly compared with the start of the experiment and E1. Bouth of UA and Creat., indicate better Condition for kidney functions.

As seen in Table (45), there was no significant variations in serum- TPtotal protein of all fish under investigation-.. Total protein level is frequently -parameter of metal poisoning in fish-. There were no significant changes in serum total protein (TP), Albumin (Alb), and Globulin (Gløb) in fish fingerlings -among -treatments. Similar- results were reported by Shalaby (2003) who exposed Nile tilapia to cadmium for 15 days, while he recorded significant decrease in these values with exposure to Cd only or with low levels of EDTA at 45 days. His study showed that liver and muscle protein was significantly decreased in fish exposed to $\mathrm{Cd}$ alone-. This result may be attributed to the great demands and cellular damage that occurred in the tissues of $\mathrm{Cd}$---toxicated fish as $\mathrm{Cd}$ toxicity may cause protein breakdown. $\mathrm{He}$ also stated that the addition of chelating agent EDTA - to $\mathrm{Cd}$ polluted media reduced significantly the retention of $\mathrm{Cd}$ in fish body and this indirectly improved the growth and biochemical changes-as reported by Shalaby (2003). James and Sampath (1999) recorded similar results with catfish Heteropneustes fossilis. Regarding the A/G ratio the obtained results indicated that there wasere significant decrease -with treatments compared to that at the start of the experiment.

On the other hand serum cholesterol level (Chol) was significantly increased in the start of the experiment. Addition of EDTA to E2, E3, E4 significantly decrease Chol. Level while with E5 its level was near that at the start of the experiment. In this connection Shalaby (2001) reported that the absorption of excess heavy metals disturbed the metabolism of lipid.

Growth performance and feed utilization. 
The effect of experimental diets on growth performance of (Sarotherodon galilaeus) are shown in Table (5) results indicate differences in growth performance parameters at $(\mathrm{P} \leqq 0.05)$ among treatments were significant. The highest final body weights, weight gains and average daily gain $(P \leqq 0.05)$ were recorded by the $E 4$ group followed by the E3 group and the other treatment groups respectively. On the other hand differences in SGR values were insignificant among the treatments groups. The lowest weight gain was obtained with diet E5 (2.0\% EDTA). The same trend was observed with average daily gain, ADG (g/fish/day) and specific growth rate, SGR (\%/day). The present results are in agreement with the findings of Shalaby (2003) who reported that Nile tilapia growth was increased significantly $(\mathrm{P} \leq 0.05)$ when fish was given 0.2 and $0.3 \mathrm{~g}$ EDTA / 1 with Cd compared to that which exposed to $\mathrm{Cd}$ alone. So 1.0 and $1.5 \%$ EDTA can be added to Galilee Tilapia fingerlings diet without adverse effect on growth performance of fish.

Table 5: Growth performance (Mean $\pm \mathrm{SE}$ ) of Galilee Tilapia fingerlings fed on diets supplemented with different levels of EDTA for 49 days.

\begin{tabular}{|c|c|c|c|c|c|}
\hline \multirow[t]{2}{*}{ Items } & \multicolumn{5}{|c|}{ Treatments } \\
\hline & E1 & E2 & E3 & E4 & E5 \\
\hline Initial body weight, IBW (g/fish) & $54.21 \pm 0.55$ & $53.63 \pm 0.23$ & $54.36 \pm 0.23$ & $53.45 \pm 0.27$ & $54.44 \pm 0.31$ \\
\hline Final body weight, FBW (g/fish) & $84.67^{b} \pm 0.95$ & $82.90^{\mathrm{bc}} \pm 0.41$ & $87.91^{\mathrm{a}} \pm 0.71$ & $88.74^{\mathrm{a}} \pm 0.16$ & $81.61^{\mathrm{c}} \pm 0.37$ \\
\hline Weight gain, WG (g/fish) & $30.46^{\mathrm{c}} \pm 0.42$ & $29.27^{\mathrm{c}} \pm 0.40$ & $33.55^{b} \pm 0.75$ & $35.16^{\mathrm{a}} \pm 0.13$ & $27.17^{\mathrm{d}} \pm 0.28$ \\
\hline Average daily gain, $\mathrm{ADG}$ g/fish/day) & $062^{\mathrm{c}} \pm 0.03$ & $0.60^{c} \pm 0.01$ & $0.68^{\mathrm{b}} \pm 0.02$ & $0.72^{\mathrm{a}} \pm 0.01$ & $0.55^{\mathrm{d}} \pm 0.01$ \\
\hline Specific growth rate, SGR (\%/day) & $0.91^{\mathrm{a}} \pm 0.04$ & $0.89^{\mathrm{a}} \pm 0.05$ & $0.98^{\mathrm{a}} \pm 0.02$ & $1.03^{\mathrm{a}} \pm 0.11$ & $0.83^{\mathrm{a}} \pm 0.03$ \\
\hline
\end{tabular}

$\mathrm{a}, \mathrm{b}$, c; means within the same row with different superscript are significant $(\mathrm{P} \leq 0.05)$.AWG $(\mathrm{g} / \mathrm{fish})=$

[Average final weight (g) - Average initial weight (g) ADG (G/fish/day) $=[$ AWG (g) /experimental period (d)], SGR $(\%$ day $)=100(\ln$ final weight $(\mathrm{g})-\ln$ initial weight $)(\mathrm{g}) /$ experimental period $(\mathrm{d})]$.

The obtained data for feed intake (FI), feed conversion ratio (FCR), protein efficiency ratio (PER), protein productive value (PPV1\%) for whole body and (PPV2\%) for fish flesh and energy utilization (EU1\%) for whole body and, (EU2\%) for fish flesh, respectively of Galilee Tilapia fingerlings are presented in Table (6). Results of this table indicated significant differences $(\mathrm{P}<0.05)$ in FCR, PER, PPV1, PPV2 among all treatments. The worst values were recorded with fish on diet E5 (2.0\% EDTA), Meanwhile the best values were obtained with fish on diet E4 (1.5\% EDTA).

Table 6: Feed utilization (Mean \pm SE) of Galilee Tilapia fingerlings fed on diets supplemented with different levels of EDTA for 49 days.

\begin{tabular}{|l|l|l|l|l|l|}
\hline \multirow{2}{*}{ Items } & \multicolumn{5}{|c|}{ Treatments } \\
\cline { 2 - 6 } & \multicolumn{1}{|c|}{ E1 } & \multicolumn{1}{|c|}{ E2 } & \multicolumn{1}{c|}{ E3 } & \multicolumn{1}{c|}{ E4 } & \multicolumn{1}{c|}{ E5 } \\
\hline Feed intake, FI (g/fish) & $71.02^{\mathrm{a}} \pm 0.4$ & $67.66^{\mathrm{b}} \pm .52$ & $72.42^{\mathrm{a}} \pm 0.2$ & $72.01^{\mathrm{a}} \pm 0.67$ & $72.32^{\mathrm{a}} \pm 0.42$ \\
\hline Feed conversion ratio, ( FCR) & $2.33^{\mathrm{b}} \pm 0.03$ & $2.31^{\mathrm{b}} \pm 0.03$ & $2.19^{\mathrm{c}} \pm 0.01$ & $2.05^{\mathrm{d}} \pm 0.03$ & $2.66^{\mathrm{a}} \pm 0.03$ \\
\hline Protein efficiency ratio, (PER) & $1.42^{\mathrm{c}} \pm 0.03$ & $1.43^{\mathrm{c}} \pm 0.02$ & $1.53^{\mathrm{b}} \pm 0.03$ & $1.62^{\mathrm{a}} \pm 0.02$ & $1.26^{\mathrm{d}} \pm 0.01$ \\
\hline Protein productive value, PPV1 (\%)* & $19.51^{\mathrm{d}} \pm 0.33$ & $21.20^{\mathrm{c}} \pm 0.19$ & $22.5^{\mathrm{b}} \pm 0.38$ & $24.89^{\mathrm{a}} \pm 0.30$ & $16.91^{\mathrm{e}} \pm 0.32$ \\
\hline Protein productive value, PPV2 (\%)** & $23.46^{\mathrm{b}} \pm 0.21$ & $23.06^{\mathrm{b}} \pm 0.84$ & $29.80^{\mathrm{a}} \pm 0.67$ & $31.40^{\mathrm{a}} \pm 0.41$ & $19.72^{\mathrm{c}} \pm 0.027$ \\
\hline Energy utilization, EU1 (\%)* & $11.40^{\mathrm{b}} \pm 0.20$ & $11.43^{\mathrm{b}} \pm 0.12$ & $10.58^{\mathrm{c}} \pm 0.23$ & $11.94^{\mathrm{a}} \pm 0.15$ & $10.60^{\mathrm{c}} \pm 0.11$ \\
\hline Energy utilization, EU2 (\%)** & $9.53^{\mathrm{b}} \pm 0.24$ & $9.42^{\mathrm{b}} \pm 0.35$ & $12.44^{\mathrm{a}} \pm 0.28$ & $12.39^{\mathrm{a}} \pm 0.17$ & $9.00^{\mathrm{c}} \pm 0.21$ \\
\hline
\end{tabular}

$\mathrm{a}, \mathrm{b}, \mathrm{c}$; means within the same row with different superscript are significantly $(\mathrm{P} \leq 0.05)$.

\section{Carcass composition of fish}

The whole fish body and fish flesh composition (\% dry matter) of Galilee Tilapia fingerlings which fed diets containing 0.0, 0.5, 1.0, 1.5, and 2.0\% of EDTA are summarized in Tables (7\&8). DM\%, CP \%, EE\%, Ash and energy content were significantly $(\mathrm{P} \leq 0.05)$ affected with the applied dietary treatments among all groups. This results indicated that the treatment E4 (1.5\% EDTA) induced increase in protein 
content while, ash content and ether extract were decreased. These results are in agreement with that obtained by James and Sampath (1999) who found similar results with catfish, $\mathrm{H}$. fossillis, when they added EDTA to Cd polluted media and showed that EDTA reduced significantly the retention of $\mathrm{Cd}$ in fish body which indirectly improved the growth and biochemical changes.

The protein content of the fish body mainly determines the quality and nutritive value of its flesh. Rengaswamy et al. (2009) reported that the reduction in the protein content after exposure to nickel chloride may be due to its effect on protein synthesis, which considered as the primary biochemical indicator for stress. This synthesizing is influenced by a large number of exogenous substances. May be due to proteolysis, lack of protein biosynthesis or inhibition of translation. Jha and Jha (1995) reported that protein content is affected negatively when fish exposed to sub-lethal concentration of cadmium.

Table 7: Whole body composition (\%DM) of Galilee Tilapia fingerlings fed on diets supplemented with different levels of EDTA for 49 days. (Mean + SE).*

\begin{tabular}{|l|l|l|l|l|l|l|}
\hline \multirow{2}{*}{ Items } & Treatments & E2 & E3 & E4 & E5 \\
\cline { 2 - 7 } & E1 & $21.18^{\mathrm{bc}} \pm 0.43$ & $20.27^{\mathrm{c}} \pm 0.32$ & $20.46^{\mathrm{bc}} \pm 0.14$ & $22.37^{\mathrm{a}} \pm 0.12$ & $21.42^{\mathrm{b}} \pm 0.11$ \\
\hline Dry matter (\%) & $21.15^{\mathrm{bc}} \pm 0.11$ & $60.04^{\mathrm{c}} \pm 0.16$ & $62.92^{\mathrm{b}} \pm 0.11$ & $63.93^{\mathrm{a}} \pm 0.29$ & $54.69^{\mathrm{e}} \pm 0.25$ & $53.41^{\mathrm{f}} \pm 0.13$ \\
\hline $\mathbf{( C P} \%)$ & $58.45^{\mathrm{d}} \pm 0.09$ & $20.72^{\mathrm{b}} \pm 0.16$ & $19.33^{\mathrm{d}} \pm 0.10$ & $18.34^{\mathrm{e}} \pm 0.11$ & $20.01^{\mathrm{c}} \pm 0.34$ & $20.57^{\mathrm{bc}} \pm 0.18$ \\
\hline EE \%) & $21.62^{\mathrm{a}} \pm 0.32$ & $15.31^{\mathrm{c}} \pm 0.16$ & $16.02^{\mathrm{b}} \pm 0.18$ & $13.36^{\mathrm{d}} \pm 0.11$ & $17.10^{\mathrm{a}} \pm 0.19$ & $15.30^{\mathrm{c}} \pm 0.24$ \\
\hline Ash (\%) & $15.0^{\mathrm{c}} \pm 0.35$ & $5477.47^{\mathrm{a}} \pm 12.16$ & $5419.42^{\mathrm{b}} \pm 11.72$ & $5494.01^{\mathrm{a}} \pm 10.68$ & $5281.29^{\mathrm{d}} \pm 7.87$ & $5358.60^{\mathrm{c}} \pm 12.39$ \\
\hline GE (Kcal /kg) & $5513.48^{\mathrm{a}} \pm 10.46$ & &
\end{tabular}

$\mathrm{a}, \mathrm{b}, \mathrm{c} ;$ means within the same row with different superscript are significantly $(\mathrm{P} \leq 0.05)$.

Crude protein (CP\%), Ether extract (EE \%), Ash (\%) and Gross energy (Kcal GE/kg)

Table 8: fish flesh composition (\%DM) of Galilee Tilapia fingerlings with different levels of EDTA throughout the experimental period (49 days) and at the start of the experiment. (Mean+SE).*

\begin{tabular}{|l|c|c|c|c|c|c|}
\hline \multirow{2}{*}{ Items } & \multicolumn{5}{|c|}{ Treatments } \\
\cline { 2 - 7 } & E1 & E2 & E3 & E4 & E5 & zero \\
\hline DM\% & $17.45^{\mathrm{bc}} \pm 0.19$ & $18.21^{\mathrm{ab}} \pm 0.16$ & $18.75^{\mathrm{a}} \pm 0.17$ & $18.90^{\mathrm{a}} \pm 0.36$ & $17.64^{\mathrm{bc}} \pm 0.30$ & $16.88^{\mathrm{c}} \pm 0.21$ \\
\hline $\mathrm{CP} \%$ & $87.50^{\mathrm{ab}} \pm 0.60$ & $87.7^{\mathrm{ab}} \pm 0.53$ & $86.26^{\mathrm{bc}} \pm 0.40$ & $89.17^{\mathrm{a}} \pm 0.84$ & $85.20^{\mathrm{c}} \pm 0.42$ & $86.13^{\mathrm{bc}} 0.32$ \\
\hline $\mathrm{EE} \%$ & $4.09^{\mathrm{abc}} \pm 0.11$ & $4.57^{\mathrm{ab}} \pm 0.23$ & $3.96^{\mathrm{bc}} \pm 0.21$ & $3.70^{\mathrm{c}} \pm 0.18$ & $4.74^{\mathrm{a}} \pm 0.34$ & $4.52^{\mathrm{ab}} \pm 0.14$ \\
\hline Ash \% & $5.16^{\mathrm{a}} \pm 0.14$ & $5.18^{\mathrm{a}} \pm 0.46$ & $5.49^{\mathrm{a}} \pm 0.12$ & $5.56^{\mathrm{a}} \pm 0.10$ & $3.53^{\mathrm{b}} \pm 0.08$ & $5.12^{\mathrm{a}} \pm 0.28$ \\
\hline GE $(\mathrm{Kcal} / \mathrm{kg})$ & $5416.6^{\mathrm{ab}} \pm 18.72$ & $5445.05^{\mathrm{ab}} \pm 15.67$ & $5376.39^{\mathrm{b}} \pm 15.98$ & $5417.37^{\mathrm{ab}} \pm 11.61$ & $5480.33^{\mathrm{a}} \pm 19.22$ & $5419.61^{\mathrm{ab}} \pm 14.77$ \\
\hline
\end{tabular}

$\mathrm{a}, \mathrm{b}, \mathrm{c}$; means within the same row with different superscript are significantly $(\mathrm{P} \leq 0.05)$.

Crude protein $(\mathrm{CP} \%)$, Ether extract (EE \%), Ash(\%) and Gross energy (Kcal GE/kg

These results suggest that EDTA could chelate $\mathrm{Pb}$ and $\mathrm{Cd}$ ions producing a stable complex. The EDTA groups eliminated more amount of $\mathrm{Cd}$ from the body through feces, and thereby improved the haematological and biochemical parameters of fish exposed to Cd as reported by Planas- Bohne and Lehman (1983) who found low level of cadmium in tissues due to increased excretion of metals through feces and urine when rats were administered Cd intravenously along with EDTA.

In conclusion The present study showed that addition of EDTA to diets of contaminated Galilee Tilapia fingerlings, reduced significantly the $\mathrm{Pb}$ and $\mathrm{Cd}$ level, helped to eliminate metal from the fish body and in turn improved the biochemical parameters as compared to non treated fish. But, in certain levels to keep the body chemical parameters in balance without any disturbance. The obtained results showed that all the tested biochemical parameters were improved due to EDTA application and they were more pronounced at $1.5 \%$ EDTA $/ \mathrm{kg}$ supplementation level, that considered as an optimum dose which could improve the healthy status of Galilee Tilapia fingerlings in our experiment. 
Abdel-Rhman, A. S.; Hossny, A. M. and El-khawas, K. M. (2009). Trials for treatment of Procambarus clarkii from hazardous pollutants and Assessment of hygienic states for consumption. Egypt. J. Aquat. Biol. \& Fish., 13(4):161-177.

AOAC. (2000). Official Methods of Analysis Association of analitical Chemists. $15^{\text {th }}$ Ed. Edited by kennesh Helrich, Arlington, Virginia 2220, USA.

APHA (American Public Health Association). (1992). Standard methods for the examination of water and wastewater. 18th ed. APHA,Washington, DC.

Ben Best, F. (2009). \EDTA\EDTA_Chemistry\CHELATION THERAPY WITH EDTA V.Imp.mht.

Castell, J.D. and K.Tiewes (1980). Report of the EIFAC, IUNS and ICES Working Group on the standardization of Methodology in Fish Research, Hamburg, FRG, 212-23 March, 1979. IFAC Tech. Pap. (3) 24.

Drupt, F. (1974). Colorimetric determination of serum albumin using boromocresol green at Ph 4.2, Pharm. Biol., (9)77:82.

Duncan, D.B. (1955). Multiple range and multiple F-tests. Biometrics, 11: 1-42.

FDA:U S Food and Drug Administration (1950). (See the US Code of Federal Regulations-21 CFR 172.135 and 21 CFR 173.315).cited from Ben, Best (2009) Fidler, M. C.; Davidsson, L.; Walczyk, T.and Hurrell, R. F. (2003). Iron absorption from fish sauce and soy sauce fortified with sodium iron EDTA. . American Journal of Clinical Nutrition, Vol. 78, No. 2, 274-278, August 2003.

Gordon Gary, M.D. (1997). Chelation Therapy. Alternative Medicine, 130. The Burton Goldberg Group, Future Medicine Publishing, Inc., Tiburon, CA. WWW Smart-publications.com Articles

Henry, R. J. (1964). Colorimetric determination of total protein. In: Clinical Chemistry. Harper and Row Publ., New York, pp 181.

Husdan, H. and A. Rapoport (1968). Estimation of Creatinine by the Jaffe reaction : A comparison of three ethods. Clin. Chem. 14:222-228.

James, R.; Sivakumar, V.; Sampath, K. and Rajendran, P. (1991). Individual and combined effects of zinc; cadmium and copper on growth of Oreochromis mossambicus. Indian. J. Fish., 38: 198- 200

James, R. and Sampath, K (1999). Effect of the ion- exchanging agent, Zeolite, on reduction of cadmium toxicity: an experimental study on growth and elemental uptake in Heteropneustes fossilis (Bloch). J. Aqua. Trop., 14 (1): 65- 74.

Jha, B.S and Jha, M.M. (1995). Biochemical effects of nickel chloride on the liver and gonads of the freshwater climbing perch. Anabas testudinus (Block), Proc. Natl. Acad. Sci. India 65 (B): 39-46.

Khater, Z. Z. K. (2011). "Ecological and Biological studies of the effect of some water pollutants on some fishes.'Ph.D. thesis, Zoology Dep. Faculty of Science, Zagazig University.

Kargin, F. (1996).Elimination of cadmium from cd-contaminated tilapiazilli in media containing edta and freshwater: changes in protein levels. Bull. Environ. Contam. Toxicol., 57:211-216

Kedziorek, M. A. M. and Bourg, A. S. M. (2000). Solubilization of lead and cadmium during the percolation of EDTA through a soil polluted by smelting activites. Contam. Hydrology., 40: 381-392.

Khan, A. T.; Diffy, B. C.; Batin, B. C.; Forester, D. M.; Thomason, S. I.; and Mielke, H. W. (1995). Heavy metals in livers and kidneys of goat in Alabama. Bull Environment Contam. Toxicol., $55: 568-573$.

Kilichling, H. and Freiburg, B. (1951). Inorganic phosphorous and alkaline 
phosphatase in serum. In Clin. Photometry. $3^{\text {rd }}$ Ed. Wiss. Verl. Ges. MbH Stutgart.

Morel, D. W.; Hessler, J.R.; Chisolm, G.M. (1987). Low-density lipoprotein cytotoxicity indeed by free radical peroxidation of lipid . J. Lipid Res., 24:1076.

Nowack, B (1996). Behavior of EDTA in groundwater- a study of the surface reactions of EDTA- metal complexes. Doctoral thesis, E. T. H. Nr: 11392. Zurich. Switzerlasnd, pp.175

Planas- Bohne, F. and Lehman, M. (1983). Influence of chelating agent on the distribution and excretion of cadmium in rats. Toxicol. Appl. Pharmacol., 67:408- 416.

Rainbow, P. S. (2007). Trace metal bioaccumulation: Models, metabolic availability and toxicity. Environmental International, 33: 576-582.

Recker,W. E. (1975). Computation and interpretation of biological statistics of fish population. Fish Res. Res. Board Can. Bull., pp.191

Reitman, S. and Frankel, S. (1957). Calorimetric determination of GPT and GOT activity. Am.j. Clin. Path., 28:56pp.

Rengaswamy, G.; Narmada, S.; Remya Vijayakumar and Cheruth Abdul Jaleel (2009). Chelating efficacy of $\mathrm{CaNa}_{2}$ EDTA on nickel-induced toxicity in Cirrhinus mrigala (Ham.) through its effects on glutathione peroxidase, reduced glutathione and lipid peroxidation. C. R. Biologies 332 (2009) 685-696.

Richmound, W. (1973). Enzymatic determination of cholesterol. Clin. Chem., 19:1350.

SAS (Statistical Analysis System) (1993): SAS/STAT user's guide release 6.03 edition. SAS Institute Inc. Cary, North Carolina

Shalaby, A. M. (1997). Biochemical and physiological studies on metal contamination in the common carp (Cyprinus carpio L). Zagazig Univ., Fac. Sci. (Benha branch). 268p. [Ph. D. Thesis].

Shalaby, A. M. (2001). Protective effect of ascorbic acid against mercury intoxication in Nile tilapia (Oreochromius niloticus). J. Egypt. Acad. Soc. Environ. Develop. (D- Environmental studies). 2 (3):79-97.

Shalaby, A.M. (2003). Effect of edta on reduction of cadmium toxicity on growth, some haematological and biochemical profiles of Nile tilapia (Oreochromi niloticus). http://ag.arizona.edu/azaqua/ista/ista7/papers/shalaby. doc. American J. Clinical Nutr., 78(2): 274-278.

Schultz (1984). "Uric acid" In: Kaplan, A (ed.), Clin. Chem., Toronto. Princeton, 418 : $1261-1266$.

Svoboda, M (2001). Stress in fish - review. Bul. VURH Vodnany., 37: 69- 191.

WHO, World Health Organization, (1992). Codex alimentarius commission, standard program codex committee on food additives and contaminants. $24^{\text {th }}$ Session, Hague, 23-28pp.

Yamawaki, K.; Hashimoto, W.; Fujii, K.; Koyama, J.; Ikeda, Y. and Ozaki, H. (1986). Hematological changes in carp exposed to low cadmium concentration . Bull of the Japanese. Soc. Sci. Fish., 59 (3):459- 466. 


\section{ARABIC SUMMARY}

أثر أضافة مادة مخلبية EDTA كأضافات غذائية للتقليل من نسب المعادن الثقيلة فى أسماك البلطى الجاليلى

\section{هيام دسوقي تونسى 1ــ عبير سعيد عبد الرحمن2}

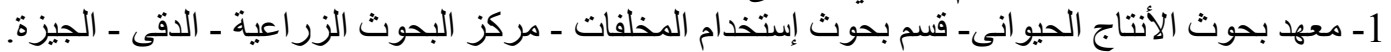

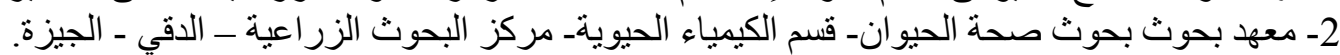

أجريت هذه التجربة لدراسة أثرإضافة EDTA كمادة مخلبية للتقليل من نسب المعادن الثقبلة

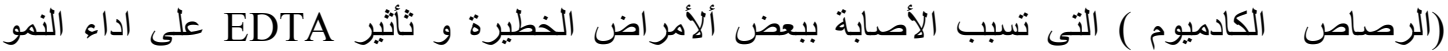
و الأستفادة من مركبات الغذاء و البروتين و تركيب الجسم و القياسات البيو كيميائية في أصبعيات البلطي البيات الجاليلي

و قد تم تجميع هذه الأسماك من منطقة قرية الظاهرية ـابو حماد ـمحافظة الثرقية، وتم تحليل العينات وحيد الجنس.

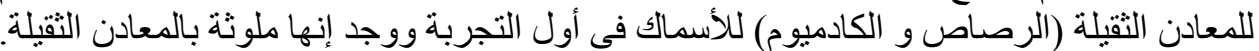
وتمت تغذية الأسمالك على خمسة معاملات و أضيفت

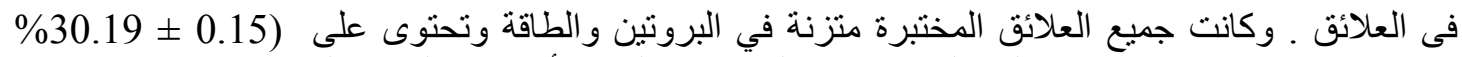

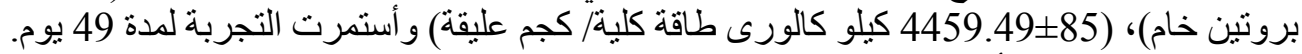

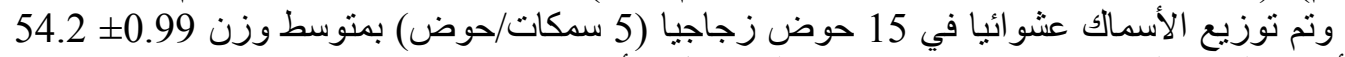

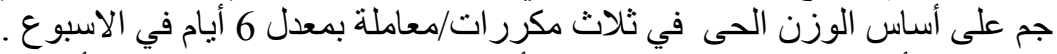

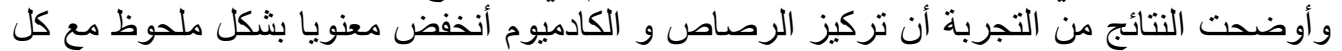

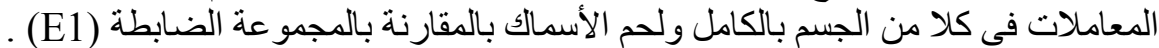

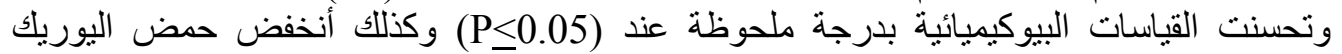

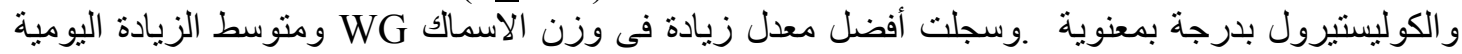

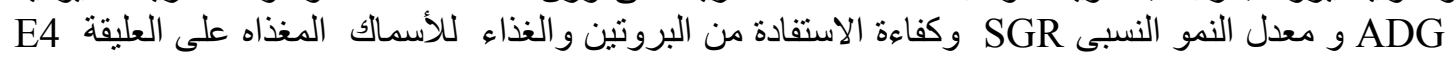

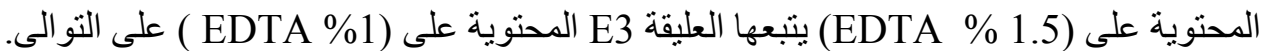

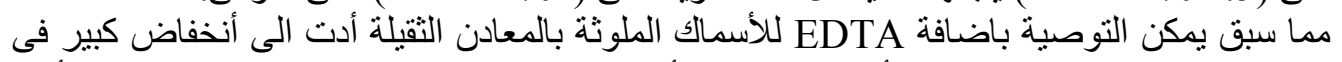

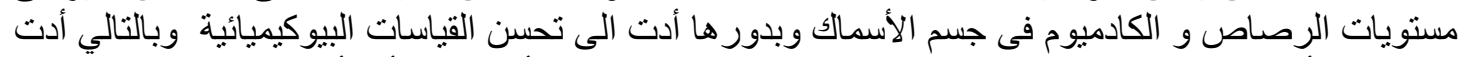

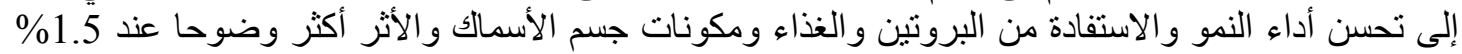

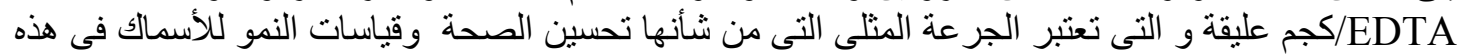

